Article

\title{
Ru-Catalyzed Repetitive Batch Borylative Coupling of Olefins in Ionic Liquids or Ionic Liquids/ $\mathrm{scCO}_{2}$ Systems
}

\author{
Jakub Szyling ${ }^{1,2, * \mathbb{D}}$, Tomasz Sokolnicki ${ }^{1,2}{ }$, Adrian Franczyk ${ }^{1}$ and Jędrzej Walkowiak ${ }^{1, * \mathbb{D}}$ \\ 1 Center for Advanced Technology, Adam Mickiewicz University in Poznań, Uniwersytetu Poznańskiego 10, \\ 61-614 Poznań, Poland; tomasz.sokolnicki@amu.edu.pl (T.S.); adrian.franczyk@amu.edu.pl (A.F.) \\ 2 Faculty of Chemistry, Adam Mickiewicz University in Poznań, Uniwersytetu Poznańskiego 8, \\ 61-614 Poznań, Poland \\ * Correspondence: j.szyling@amu.edu.pl (J.S.); jedrzej.walkowiak@amu.edu.pl (J.W.)
}

Received: 8 June 2020; Accepted: 5 July 2020; Published: 8 July 2020

\begin{abstract}
The first, recyclable protocol for the selective synthesis of (E)-alkenyl boronates via borylative coupling of olefins with vinylboronic acid pinacol ester in monophasic (cat@IL) or biphasic (cat@IL/ $\mathrm{scCO}_{2}$ ) systems is reported in this article. The efficient immobilization of $\left[\mathrm{Ru}(\mathrm{CO}) \mathrm{Cl}(\mathrm{H})\left(\mathrm{PCy}_{3}\right)_{2}\right](1 \mathrm{~mol} \%)$ in $[\mathrm{EMPyr}]\left[\mathrm{NTf}_{2}\right]$ and [BMIm] [OTf] with the subsequent extraction of products with $n$-heptane permitted multiple reuses of the catalyst without a significant decrease in its activity and stability (up to 7 runs). Utilization of $\mathrm{scCO}_{2}$ as an extractant enabled a significant reduction in the amount of catalyst leaching during the separation process, compared to extraction with $n$-heptane. Such efficient catalyst immobilization allowed an intensification of the processes in terms of its productivity, which was indicated by high cumulative TON values (up to 956) in contrast to the traditional approach of applying volatile organic solvents ( $\mathrm{TON}=\sim 50-100)$. The reaction was versatile to styrenes with electron-donating and withdrawing substituents and vinylcyclohexane, generating unsaturated organoboron compounds, of which synthetic utility was shown by the direct transformation of extracted products in iododeborylation and Suzuki coupling processes. All synthesized compounds were characterized using ${ }^{1} \mathrm{H},{ }^{13} \mathrm{C}$ NMR and GC-MS, while leaching of the catalyst was detected with ICP-MS.
\end{abstract}

Keywords: homogeneous catalysis; ionic liquids; supercritical $\mathrm{CO}_{2}$; borylative coupling; catalyst recycling; green chemistry; ruthenium catalyst; vinyl boronates; organoboron compounds

\section{Introduction}

Homogeneous catalysis has remained a key part of chemistry for several decades and is a powerful tool in the synthesis of valuable compounds. The high activity and selectivity of molecular catalysts under mild reaction conditions, the lack of diffusion barriers in comparison to heterogeneous systems, and the variability of their electronic and steric properties tuned by the proper design and choice of ligands and metal centers lead to their application in the chemical industry in the production of advanced polymers and fine chemicals $[1,2]$. On the other hand, homogeneous conditions generate notable problems in recovery and reuse of catalysts, which are mostly based on expensive noble transition metals (TM), for example, rhodium, iridium, platinum, palladium, or ruthenium. To obtain high TON values and the proper process selectivity, this precious catalyst is often sacrificed within the separation process. Moreover, homogeneous conditions require a considerable amount of volatile organic solvent to dissolve all reaction components: reagents and catalysts. Such an approach generates problems with the process economy resulting from the high solvent consumption within the process 
and separation but also influences toxicological and environmental aspects. As a consequence of these drawbacks, new more sustainable methods for the synthesis of advanced organic and organometallic molecules by the application of environmentally benign solvents and/or catalyst immobilization and recycling are continuously being developed in academia and industry [3-8].

Ionic liquids (ILs) constitute an interesting green alternative to typical organic solvents because of their unique properties, such as incombustibility, negligible vapor pressure and abilities for the dissolution of many inorganic, organic and organometallic compounds. As a result of their physicochemical properties, ILs have immense structural variability which results in a wide range of their applications, for example, lubricants [9,10], solar cells [11,12], biomass processing [13,14] and solvents in chemical syntheses [15-17]. Their affinity to TM-complexes, as well as their high polarity, mean that ILs are frequently used in catalysis as a typical solvent, ligand source or even the catalyst itself. Moreover, ILs can also be used for catalyst immobilization, very often without any interference in its structure, and therefore without affecting its initial activity.

An efficient immobilization of the catalyst in IL and a properly designed product separation strategy significantly reduce metal leaching into the final product and allow for the recycling of the expensive TM-complex. This can be achieved by the extraction of products from the ionic phase through organic solvents or more preferably, supercritical $\mathrm{CO}_{2}\left(\mathrm{scCO}_{2}\right)$ [18]. Combining ILs and scCO permits the development of an approach benefitting from the advantages of both homogeneous and heterogeneous catalysis, i.e., (i) high catalyst activity, selectivity, and stability, (ii) solvent(IL) and catalyst recyclability (iii) enhanced productivity and (iv) product separation simplicity. Moreover, the presence of $\mathrm{scCO}_{2}$ significantly reduces the viscosity of ILs facilitating mass transfer, increasing the reaction rate and allows for effective extraction of the products by compressed $\mathrm{CO}_{2}$ from ILs [19].

There are a lot of examples of ILs and $\mathrm{scCO}_{2}$ being used as benign, eco-friendly alternative solvents in many catalytic processes such as hydrogenations [20,21], oxidations [22], hydroformylations [23], Pd-catalyzed C-C bond-forming couplings [24], hydrometallations [25-27] or silylative coupling [28]. These solvents permit catalyst immobilization in liquid or solid-state, and processes to be carried out under repetitive batch and continuous flow methods. Our group also has experience in the application of green solvents (ILs, $\mathrm{scCO}_{2}, \mathrm{PEGs}$ ) in designing sustainable protocols for the synthesis of organoboron and organosilicon compounds by the immobilization of the molecular catalyst and their recycling [29-35].

Due to their low toxicity, high reactivity under specified reaction conditions, and ease of handling, these organometallic compounds are valuable synthons in many chemical transformations, for example, Suzuki or Hiyama couplings [36,37] or halodemetalations [34,38]. Most of the organosilicon and organoboron compounds are produced under homogeneous conditions, with the use of TM-complexes as catalysts, thus searching for efficient and more sustainable protocols for their preparation is of great importance.

The utilization of ILs and/or $\mathrm{scCO}_{2}$ for the synthesis of unsaturated organoboron compounds is poorly explored. Up to date, only three reports focusing on the catalytic hydroboration of alkynes in these solvents have been described [30,31,39]. Because of the challenging regio- and stereoselectivity control of the catalytic hydroboration of alkynes, the exclusive formation of one isomer was difficult to achieve, despite the good or very good recyclability and stability of catalytic systems. In contrast to the catalytic hydroboration of alkynes, borylative coupling (trans-borylation) of vinyl boronates with olefins, especially styrene derivatives, in the presence of ruthenium hydride catalysts, smoothly leads to the exclusive formation of $(E)$-alkenyl boronates [40].

In continuation of our studies on the application of green solvents in the synthesis of unsaturated organoboron compounds, herein, we would like to report the first application of ILs and the $\mathrm{Ru}-\mathrm{H}$ catalyst $\left[\mathrm{Ru}(\mathrm{CO}) \mathrm{Cl}(\mathrm{H})(\mathrm{PCy})_{2}\right]$ in the monophasic $\left(\left[\mathrm{Ru}(\mathrm{CO}) \mathrm{Cl}(\mathrm{H})(\mathrm{PCy})_{2}\right] @ \mathrm{ILs}\right)$ or biphasic $\left(\left[\mathrm{Ru}(\mathrm{CO}) \mathrm{Cl}(\mathrm{H})\left(\mathrm{PCy}_{3}\right)_{2}\right] @ \mathrm{ILs} / \mathrm{scCO}_{2}\right)$ recyclable borylative coupling of vinylboronic acid pinacol ester with olefins (Scheme 1). The presented method is an interesting variant of traditional protocols through 
(i) the ability of catalysts and ILs to recycle, (ii) product separation simplicity, (iii) the high productivity and stability of the systems.

\begin{tabular}{|c|c|c|}
\hline $\begin{array}{c}\text { Previous works } \\
\text { TM-catalyzed alkyne hydroboration } \\
\text { see ref.:[30-31], [39] }\end{array}$ (E)-alkenyl boronates & $\begin{array}{c}\text { Our work } \\
\text { cat@ILs or }\end{array}$ \\
cat. = catalyst, ILs = ionic liquids
\end{tabular}

Scheme 1. Ionic liquids-based recyclable protocols for the synthesis of unsaturated organoboron compounds.

\section{Results and Discussion}

\subsection{Reaction and Extraction Conditions Screening}

The studies were initiated by an investigation of the borylative coupling of vinylboronic acid pinacol ester (1) with styrene (2a) as a model reaction performed in several ILs based on pyrrolidinium $\left([\mathrm{EMPyr}]^{+}\right)$or 1-butyl-3-methylimidazolium $\left([\mathrm{BMIm}]^{+}\right)$cations and various inorganic and organic anions (Figure 1). Most of them were successfully applied in TM-catalyzed transformations [16]. Borylative coupling is a catalytic reaction which occurs in the presence of $\mathrm{Ru}-\mathrm{H}$ catalysts with the activation of the $\mathrm{C}-\mathrm{B}$ bond in vinyl boronates and the $\mathrm{C}-\mathrm{H}$ bond in olefins or $\mathrm{O}-\mathrm{H}$ bond in alcohols, silanols or boronic acids furnishing boryl-substituted olefins, boronic esters, borasiloxanes or boroxanes respectively, with the simultaneous evolution of ethylene [29,40-43].

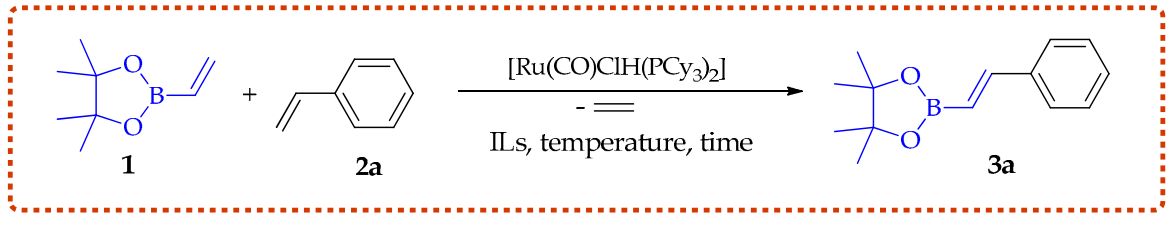

Pyrrolidinium-based ionic liquids

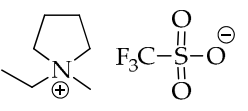

[EMPyr][OTf]
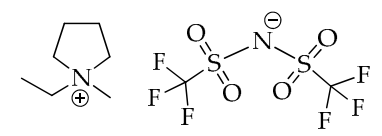

$[\mathrm{EMPyr}]\left[\mathrm{NTf}_{2}\right]$

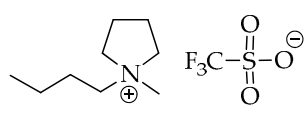

[BMPyr][OTf]
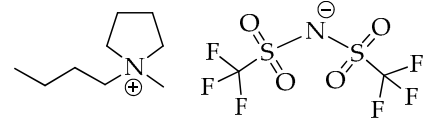

$[\mathrm{BMPyr}]\left[\mathrm{NTf}_{2}\right]$

Imidazolium-based ionic liquids
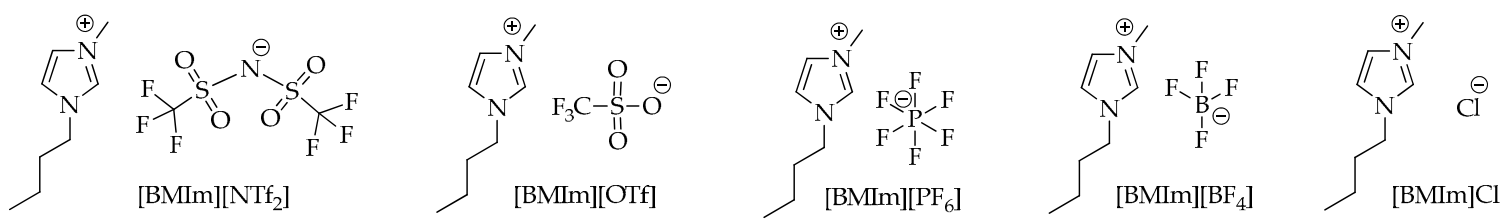

Figure 1. Model reaction of $\mathbf{1}$ with 2a used for the conditions screening. Pyrrolidinium and imidazolium-based ionic liquids used as solvents and catalyst immobilization media.

For the initial ionic liquids screening, we applied slightly more rigorous reaction conditions if compared to the traditional approach of utilizing volatile organic solvents (a higher process temperature to ensure good homogeneity of the reaction mixture). $\left[\mathrm{Ru}(\mathrm{CO}) \mathrm{Cl}(\mathrm{H})\left(\mathrm{PCy}_{3}\right)_{2}\right]$ was used as a catalyst, which was previously described as the most effective in this transformation. In all pyrrolidinium-based ionic liquids, a conversion of 1 was over $90 \%$ (Table 1, entry 1-4). The complete conversion of 1 was observed only for [EMPyr] $\left[\mathrm{NTf}_{2}\right]$. In general, a higher conversion of $\mathbf{1}$ was observed for pyrrolidinium cations with ethyl substituents. When butyl groups were attached to the pyrrolidinium cation, 
the product yield was slightly lower. Simultaneously, the application of trifluoromethanesulfonate anion $\left([\mathrm{OTf}]^{-}\right)$resulted in the lower conversion of substrates than for bis(trifluoromethylsulfonyl)imide anion $\left(\left[\mathrm{NTf}_{2}\right]^{-}\right)$.

Table 1. Borylative coupling of vinylboronic acid pinacol ester (1) with styrene (2a) in the presence of $\left[\mathrm{Ru}(\mathrm{CO}) \mathrm{Cl}(\mathrm{H})\left(\mathrm{PC} \mathrm{y}_{3}\right)_{2}\right] @ I L-I L$ screening. IL-Ionic liquids.

\begin{tabular}{|c|c|c|c|}
\hline Entry & Ionic Liquid & Conversion of $1[\%]^{a}$ & Yield of $3 a[\%]^{b}$ \\
\hline 1 & [EMPyr][OTf] & 95 & 95 \\
\hline 2 & [EMPyr][NTf $\left.f_{2}\right]$ & 100 & 100 \\
\hline 3 & [BMPyr][OTf] & 91 & 91 \\
\hline 4 & {$[\mathrm{BMPyr}]\left[\mathrm{NTf}_{2}\right]$} & 93 & 93 \\
\hline 5 & {$[\mathrm{BMIm}]\left[\mathrm{NTf}_{2}\right]$} & 97 & 97 \\
\hline 6 & [BMIm][OTf] & 100 & 100 \\
\hline 7 & {$[\mathrm{BMIm}]\left[\mathrm{PF}_{6}\right]$} & 88 & 88 \\
\hline 8 & {$[\mathrm{BMIm}]\left[\mathrm{BF}_{4}\right]$} & 54 & 54 \\
\hline 9 & [BMIm] $\mathrm{Cl}$ & trace & n.d \\
\hline
\end{tabular}

Reaction conditions: $[\mathrm{Ru}-\mathrm{H}]: 1: 2 \mathrm{a}=0.03: 1: 4,130^{\circ} \mathrm{C}$, ionic liquid $(1 \mathrm{~g})$, inert atmosphere. ${ }^{\mathrm{a}}$ Determined by GC-MS.

${ }^{\mathrm{b}}$ Determined by GC-MS and ${ }^{1} \mathrm{H}$ NMR.

Borylative coupling of $\mathbf{1}$ with $\mathbf{2 a}$ in 1-butyl-3-methylimidazolium-based ionic liquids with [OTf] ${ }^{-}$ or $\left[\mathrm{NTf}_{2}\right]^{-}$anions occurred smoothly with very high yields with the formation of the desired product 3a and excellent selectivity (Table 1, entry 5-6). In contrast to pyrrolidinium cation, the quantitative conversion of 1 was observed for [OTf] $]^{-}$anion. Lower yields were observed when moisture-sensitive anions such as hexafluorophosphate $\left(\left[\mathrm{PF}_{6}\right]\right)^{-}$or tetrafluoroborate $\left(\left[\mathrm{BF}_{4}\right]\right)^{-}$were used (Table 1, entry $\left.7-8\right)$. The presence of traces of water in those ILs probably caused partial deactivation of the moisture-sensitive catalyst. When [BMIm] $\mathrm{Cl}$ was used as a solvent and immobilization medium, no conversion of $\mathbf{1}$ was noticed. This can be explained by the strong coordination ability of chloride anion to the metal center of the catalyst, and inhibition of its activity. This observation is in agreement with previous reports [28,30].

[EMPyr][NTf ${ }_{2}$ ] and [BMIm][OTf], which ensured the complete conversion of $\mathbf{1}$ (Table 1, entry 2 and 6), were chosen for further reaction conditions screening. We optimized parameters crucial for obtaining the highest reaction yield, i.e., temperature, time, the molar ratio of substrates, as well as catalyst loading (Table 2). Initially, for [EMPyr][NTf $\left.{ }_{2}\right]$, the high catalyst loading of $\left[\mathrm{Ru}(\mathrm{CO}) \mathrm{Cl}(\mathrm{H})\left(\mathrm{PCy}_{3}\right)_{2}\right](3 \mathrm{~mol} \%)$ was maintained while the other parameters were tuned. The quantitative yields of $3 a$ were observed above $110{ }^{\circ} \mathrm{C}$. The same results were noticed when the time of the reaction was reduced from 24 to $6 \mathrm{~h}$. Moreover, only a 1.5-fold excess of $2 \mathrm{a}$ towards 1 was necessary to get a full conversion of $\mathbf{1}$. In the final stage of optimization studies in [EMPyr][NTf 2 ], the influence of catalyst loading on reaction efficiency was determined. It was found that $1 \mathrm{~mol} \%$ of $\left[\mathrm{Ru}(\mathrm{CO}) \mathrm{Cl}(\mathrm{H})\left(\mathrm{PCy}_{3}\right)_{2}\right]$ is essential for achieving a very high reaction yield (Table 2, entry 12). Although the application of the equimolar ratio of substrates resulted in a complete conversion of $\mathbf{1}$, the presence of a homocoupling product of $\mathbf{1}$ was observed (Table 2, entry 14). Therefore, a small excess of olefin is essential for the elimination of the side-homocoupling reaction of vinyl boronate. Replacement of ruthenium hydride catalyst with coordinated $\mathrm{PC}_{3}$ ligand to $\left[\mathrm{Ru}(\mathrm{CO}) \mathrm{Cl}(\mathrm{H})\left(\mathrm{PPh}_{3}\right)_{3}\right]$ leads to a lower conversion of $\mathbf{1}$ and the formation of undefined by-products (Table 2, entry 15).

Based on the most effective reaction conditions in [EMPyr][NTf $f_{2}$, borylative coupling of $\mathbf{1}$ with 2a in [BMIm][OTf] was determined. Similar to pyrrolidinium-based IL, the reaction in [BMIm][OTf] should be performed at least at $110{ }^{\circ} \mathrm{C}$ for $6 \mathrm{~h}$ with a slight excess of $2 \mathrm{a}$ towards 1 and $1 \mathrm{~mol} \%$ of $\left[\mathrm{Ru}(\mathrm{CO}) \mathrm{Cl}(\mathrm{H})\left(\mathrm{PCy}_{3}\right)_{2}\right]$, to achieve the best process efficiency (Table 2, entry 16). It is worth emphasizing that the application of ILs as a solvent enhances reaction rate compared to an analogous reaction performed in poly (ethylene glycol), another green solvent with similar properties to ILs [29] The same phenomenon has already been observed by us during studies on the catalytic hydroboration of alkynes in $\mathrm{Ru}(\mathrm{CO}) \mathrm{Cl}(\mathrm{H})\left(\mathrm{PPh}_{3}\right)_{3} @ \mathrm{ILs}$ systems [30]. 
Table 2. Reaction conditions screening for borylative coupling of $\mathbf{1}$ with $\mathbf{2 a}$ in the presence of immobilized $\left[\mathrm{Ru}(\mathrm{CO}) \mathrm{Cl}(\mathrm{H})\left(\mathrm{PCy}_{3}\right)_{2}\right] @[\mathrm{EMPyr}]\left[\mathrm{NTf}_{2}\right]$ or @[BMIm][OTf].

\begin{tabular}{|c|c|c|c|c|c|c|c|}
\hline Entry & Ionic Liquid & $\begin{array}{c}\text { Temperature } \\
{\left[{ }^{\circ} \mathrm{C}\right]}\end{array}$ & $\begin{array}{l}\text { Time } \\
{[\mathrm{h}]}\end{array}$ & $\begin{array}{c}1: 2 \mathrm{a} \\
{[\mathrm{mol}]}\end{array}$ & $\begin{array}{l}\text { Catalyst Loading } \\
{[\mathrm{mol} \%]}\end{array}$ & $\begin{array}{c}\text { Conversion } \\
\text { of } 1[\%]^{a}\end{array}$ & $\begin{array}{l}\text { Yield of } 3 a \\
\qquad \%]^{b}\end{array}$ \\
\hline 1 & {$[\mathrm{EMPyr}]\left[\mathrm{NTf}_{2}\right]$} & 120 & & $1: 4$ & 3 & 100 & 100 \\
\hline 2 & {$[\mathrm{EMPyr}]\left[\mathrm{NTf}_{2}\right]$} & 110 & 24 & $1: 4$ & 3 & 100 & 100 \\
\hline 3 & {$[\mathrm{EMPyr}]\left[\mathrm{NTf}_{2}\right]$} & 100 & 24 & $1: 4$ & 3 & 96 & 96 \\
\hline 4 & {$[\mathrm{EMPyr}]\left[\mathrm{NTf}_{2}\right]$} & 80 & 24 & $1: 4$ & 3 & 88 & 88 \\
\hline 5 & {$[\mathrm{EMPyr}]\left[\mathrm{NTf}_{2}\right]$} & 110 & 18 & $1: 4$ & 3 & 100 & 100 \\
\hline 6 & {$[\mathrm{EMPyr}]\left[\mathrm{NTf}_{2}\right]$} & 110 & 6 & $1: 4$ & 3 & 100 & 100 \\
\hline 7 & {$[\mathrm{EMPyr}]\left[\mathrm{NTf}_{2}\right]$} & 110 & 3 & $1: 4$ & 3 & 94 & 94 \\
\hline 8 & {$[\mathrm{EMPyr}]\left[\mathrm{NTf}_{2}\right]$} & 110 & 6 & $1: 3$ & 3 & 100 & 100 \\
\hline 9 & {$[\mathrm{EMPyr}]\left[\mathrm{NTf}_{2}\right]$} & 110 & 6 & $1: 2$ & 3 & 100 & 100 \\
\hline 10 & {$[\mathrm{EMPyr}]\left[\mathrm{NTf}_{2}\right]$} & 110 & 6 & $1: 2$ & 2 & 100 & 100 \\
\hline 11 & {$[\mathrm{EMPyr}]\left[\mathrm{NTf}_{2}\right]$} & 110 & 6 & 1:1.5 & 2 & 100 & 100 \\
\hline 12 & {$[\mathrm{EMPyr}]\left[\mathrm{NTf}_{2}\right]$} & 110 & 6 & 1:1.5 & 1 & 100 & 100 \\
\hline 13 & {$[\mathrm{EMPyr}]\left[\mathrm{NTf}_{2}\right]$} & 110 & 6 & 1:1.5 & 0.5 & 93 & 93 \\
\hline 14 & {$[\mathrm{EMPyr}]\left[\mathrm{NTf}_{2}\right]$} & 110 & 6 & $1: 1$ & 1 & 100 & $83^{c}$ \\
\hline $15^{\mathrm{d}}$ & {$[\mathrm{EMPyr}]\left[\mathrm{NTf}_{2}\right]$} & 110 & 6 & $1: 1.5$ & 1 & 46 & $37^{\mathrm{e}}$ \\
\hline 16 & [BMIm][OTf] & 110 & 6 & 1:1.5 & 1 & 100 & 100 \\
\hline 17 & [BMIm][OTf] & 80 & 6 & $1: 1.5$ & 1 & 53 & 53 \\
\hline 18 & [BMIm][OTf] & 110 & 3 & 1: 1.5 & 1 & 91 & 91 \\
\hline 19 & [BMIm][OTf] & 110 & 6 & $1: 1$ & 1 & 100 & $88^{c}$ \\
\hline $20^{d}$ & [BMIm][OTf] & 110 & 6 & 1: 1.5 & 1 & 41 & $33^{e}$ \\
\hline 21 & [BMIm][OTf] & 110 & 6 & 1: 1.5 & 0.5 & 89 & 89 \\
\hline
\end{tabular}

Among many possibilities for the separation of products from the homogeneous reaction mixture, extraction seems to be a fast and efficient method. The extractant should dissolve the reaction products well, not mix with an ionic liquid to prevent leaching of the catalyst, as well as not inhibiting or deactivating the catalyst. The right choice is crucial for the ability to reuse the catalytic system. To find the most appropriate medium for product extraction, we examined several organic solvents and $\mathrm{scCO}_{2}$ (Table 3). Non-polar aliphatic hydrocarbons ( $n$-hexane or $n$-heptane) are completely immiscible with [EMPyr][ $\left.\mathrm{NTf}_{2}\right]$ and [BMIm][OTf], and during the extraction, the two phases were observed. The extractant (upper) phase was transparent or pale yellow. Application of more polar solvents such as toluene, dichloromethane or tetrahydrofuran resulted in partial or complete dissolution of the catalytic systems regardless of the ionic liquid used.

Table 3. Extractant screening.

\begin{tabular}{cccc}
\hline Entry & Solvent & [EMPyr][NTf $\left.{ }_{2}\right]$ & [BMIm][OTf] \\
\hline $1^{\mathrm{a}}$ & $n$-Hexane & - & - \\
$2^{\mathrm{a}}$ & $n$-Heptane & - & - \\
$3^{\mathrm{a}}$ & Toluene & + & + \\
$4^{\mathrm{b}}$ & Dichloromethane & + & + \\
$5^{\mathrm{a}}$ & Tetrahydrofuran & + & + \\
$6^{\mathrm{c}}$ & Supercritical $\mathrm{CO}_{2}$ & - & - \\
\hline
\end{tabular}

Extraction conditions: $3 \times 5 \mathrm{~mL}$ of the solvent at ${ }^{\mathrm{a}} 60$ or $^{\mathrm{b}} 40^{\circ} \mathrm{C} .{ }^{\mathrm{c}} 160-180$ bar of $\mathrm{CO}_{2}$ at $\left.40{ }^{\circ} \mathrm{C}, 8 \mathrm{~mL} / \mathrm{min}, 45 \mathrm{~min}\right)$. (-) Biphasic system. (+) Monophasic system or catalyst leaching from IL.

Similar to aliphatic hydrocarbons, $\mathrm{ScCO}_{2}$ creates a biphasic solvent system with [EMPyr] $\mathrm{NTf}_{2}$ ] and [BMIm][OTf]. Additionally, it is known that $\mathrm{scCO}_{2}$ is partially soluble in ILs, lowering their viscosity, while ILs are not soluble in this supercritical fluid. Therefore, such a biphasic system is suitable for carrying out the reaction/extraction process [44]. Based on extractant screening for further 
experiments, $n$-heptane (lower neurotoxicity than $n$-hexane) and $\mathrm{scCO}_{2}$ were chosen as solvents for product extraction from the post-reaction mixtures.

\subsection{Scope of Substrates Investigations}

Having optimized the reaction and extraction conditions in hand, we have studied a scope of olefins, mainly electron-deficient, neutral or donating styrenes, in borylative coupling with $\mathbf{1}$ in [BMIm][OTf] (Table 4). The reaction of 1 with bromo-(2b) or fluoro-substitued (2c) styrenes in para position led to (E)-alkenyl boronates with high yields (Table 4, entry 2-3). Application of electron-withdrawing groups such as $-\mathrm{CF}_{3}(\mathbf{2} \mathbf{d}-\mathbf{e})$ also gave an excellent conversion of $\mathbf{1}$. Trans-borylation of $\mathbf{1}$ with a weakly donating $-\mathrm{CH}_{3}$ groups in meta $(\mathbf{2} \mathbf{f})$ or para $(2 \mathrm{~g})$ positions resulted in the desired products $3 \mathbf{f}$ and $\mathbf{3 g}$ with very good isolation yields (Table 4, entry 6-7). However, the utilization of the sterically hindered alkyl group $-\mathrm{C}\left(\mathrm{CH}_{3}\right)_{3}(\mathbf{2 h})$ gave a lower conversion of $\mathbf{1}$. A similar result was noticeable when the electron-donating $-\mathrm{OCH}_{3}$ group (2i) was applied. We also examined the reactivity of vinylcyclohexane $(\mathbf{2} \mathbf{j})$ in borylative coupling with $\mathbf{1}$. After $6 \mathbf{h}, \mathbf{3} \mathbf{j}$ was observed with a very high yield (Table 4, entry 10 ).

Table 4. Borylative coupling of $\mathbf{1}$ with a various olefins $\mathbf{2 a}-\mathbf{j}$ in $\mathrm{Ru}(\mathrm{CO}) \mathrm{Cl}(\mathrm{H})\left(\mathrm{PCy}_{3}\right)_{2} @[\mathrm{BMIm}][\mathrm{OTf}]$ in optimized reaction and extraction conditions.
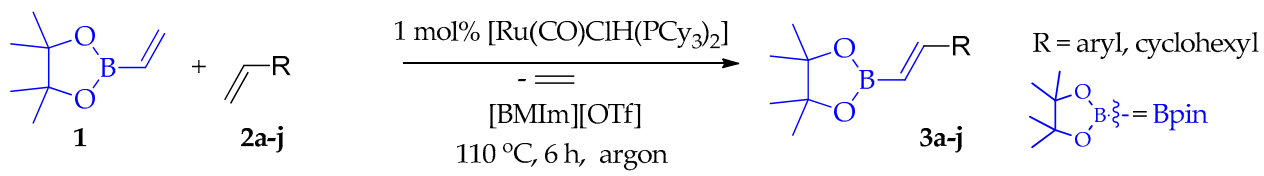

\begin{tabular}{|c|c|c|c|c|c|c|c|}
\hline Entry & Olefin & 2 & Product & 3 & $\begin{array}{c}\text { Conversion of } 1 \\
{[\%]^{\mathrm{a}}}\end{array}$ & $\begin{array}{c}\text { Extraction Yield } \\
{[\%]^{\mathrm{b}}}\end{array}$ & $\begin{array}{c}\text { Isolation Yield } \\
{[\%]^{\mathrm{c}}}\end{array}$ \\
\hline 1 & & $\mathbf{a}$ & & $\mathbf{a}$ & 100 & $\begin{array}{l}94^{\mathrm{d}} \\
90^{\mathrm{e}}\end{array}$ & 81 \\
\hline 2 & & b & & b & 99 & $\begin{array}{l}91^{\mathrm{d}} \\
88^{\mathrm{e}}\end{array}$ & 77 \\
\hline 3 & & c & & c & 99 & $\begin{array}{l}90^{\mathrm{d}} \\
91^{\mathrm{e}}\end{array}$ & 78 \\
\hline 4 & & $\mathrm{~d}$ & & d & 100 & $\begin{array}{l}93^{\mathrm{d}} \\
94^{\mathrm{e}}\end{array}$ & 83 \\
\hline 5 & & e & & e & 99 & $\begin{array}{l}90^{\mathrm{d}} \\
92^{\mathrm{e}}\end{array}$ & 81 \\
\hline 6 & & $\mathrm{f}$ & & $\mathrm{f}$ & 100 & $\begin{array}{l}93^{\mathrm{d}} \\
91^{\mathrm{e}}\end{array}$ & 79 \\
\hline 7 & & $\mathrm{~g}$ & & g & 98 & $\begin{array}{l}84^{\mathrm{d}} \\
81^{\mathrm{e}}\end{array}$ & 69 \\
\hline 8 & & h & & $\mathrm{h}$ & 93 & $\begin{array}{l}81^{\mathrm{d}} \\
77^{\mathrm{e}}\end{array}$ & 73 \\
\hline 9 & & i & & $\mathrm{i}$ & 89 & $\begin{array}{l}74^{\mathrm{d}} \\
75^{\mathrm{e}}\end{array}$ & 71 \\
\hline 10 & & $\mathrm{j}$ & & $\mathbf{j}$ & 100 & $\begin{array}{l}95^{\mathrm{d}} \\
96^{\mathrm{e}}\end{array}$ & 87 \\
\hline
\end{tabular}

Reaction conditions: [Ru-H]:1:2a-j $=0.01: 1: 1.5, \quad 110{ }^{\circ} \mathrm{C}, 6 \mathrm{~h}, 1 \mathrm{~g}$ [BMIm][OTf], inert atmosphere. Extraction conditions: $3 \times 5 \mathrm{~mL}$ of the $n$-heptane at $60{ }^{\circ} \mathrm{C}$ or $160-180$ bar of $\mathrm{CO}_{2}$ at $40{ }^{\circ} \mathrm{C}, 8 \mathrm{~mL} / \mathrm{min}, 45 \mathrm{~min}$. a Determined by GC-MS. ${ }^{\mathrm{b}}$ Calculated on total amount of reagents. ${ }^{\mathrm{c}}$ After $n$-heptane extraction; calculated on a

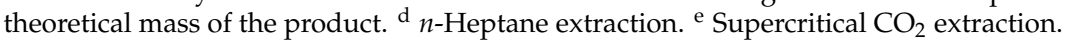


Simultaneously, the efficiency of extraction for different products of 3 was investigated. $n$-Heptane $\left(3 \times 5 \mathrm{~mL}\right.$ at $\left.60^{\circ} \mathrm{C}\right)$ or $\mathrm{scCO}_{2}\left(160-180\right.$ bar of $\mathrm{CO}_{2}$ at $\left.40^{\circ} \mathrm{C}, 8 \mathrm{~mL} / \mathrm{min}, 45 \mathrm{~min}\right)$ were applied as extractants. Very high extraction yields (over $90 \%$ ) using $n$-heptane were obtained for most of the products (3a-f, $\mathbf{3} \mathbf{j}$ ). Similar results were achieved for the product extraction with $\mathrm{scCO}_{2}$. It is worth noticing that when $\mathrm{CO}_{2}$-philic groups such as $-\mathrm{F}$ or $-\mathrm{CF}_{3}$ were attached to the phenyl rings $(3 \mathbf{c}-\mathbf{e})$, the extraction yields in $\mathrm{scCO}_{2}$ were slightly higher (Table 4 , entry $3-5$ ). The extraction of product $3 \mathbf{j}$ with a cyclohexyl ring was almost quantitative due to its good affinity to both extractants.

\subsection{Repetitive Batch Borylative Coupling in the Monophasic Solvent System- $\left[\mathrm{Ru}(\mathrm{CO}) \mathrm{Cl}(\mathrm{H})\left(\mathrm{PC} y_{3}\right)_{2}\right] @ I L s$}

A key objective of our research was to develop an efficient and more sustainable protocol for the synthesis of $(E)$-alkenyl boronates via borylative coupling of vinyl boronates with olefins in ILs. Having optimized the process (reaction and extraction) conditions, as well as the information on the reactivity of olefins (2a-j), we verified the possibility of catalytic system recycling after each run using [BMIm][OTf] and [EMPyr][NTf 2 ] as solvents. For repetitive batch borylative coupling of $\mathbf{1}$ with olefins, $\mathbf{2 a}$, and $\mathbf{2 d}$ were chosen as reagents due to their excellent reaction and extraction yields. Trans-borylation of 1 with 2a in [BMIm][OTf] and [EMPyr][NTf 2 ] (Figure 2a,b) gave a final product 3a with very high yields up to the sixth run. For both ionic liquids, a gradual decrease in the reaction yield in the seventh up to the 10th cycle was observed. A higher extraction yield for extractant-soluble components ( $3 \mathbf{a}$ and excess or unreacted substrate) was noticed when $n$-heptane was used. Moreover, the cumulative turnover number (cTON) was several times higher than in the classical approach, utilizing volatile organic solvents (930-948 vs. approx. 50-100).

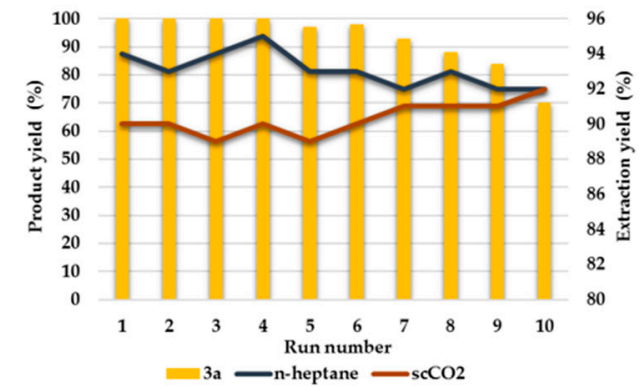

(a)

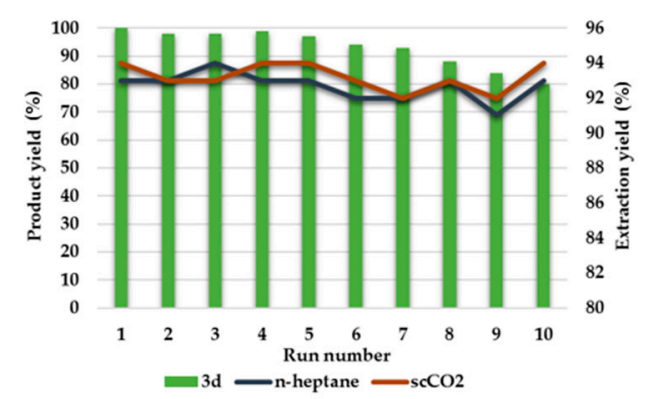

(c)

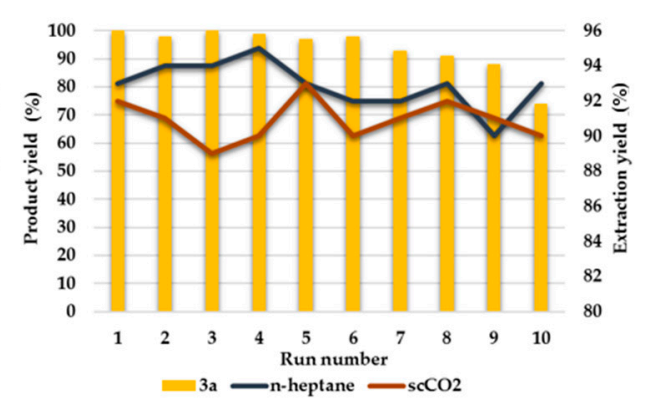

(b)

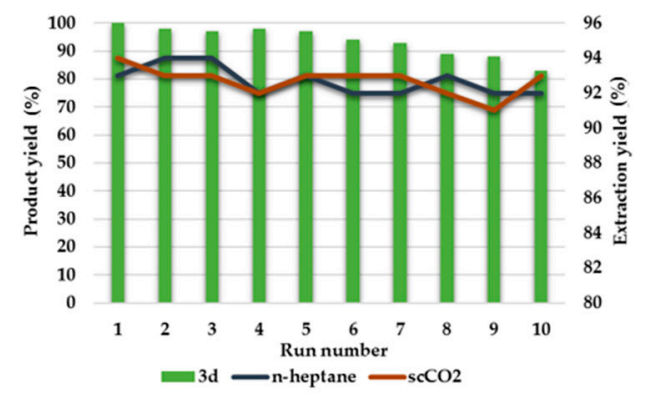

(d)

Figure 2. Repetitive batch borylative coupling of $\mathbf{1}$ with $2 \mathrm{a}$ in [BMIm][OTf] (a) and [EMPyr][NTf $\mathrm{N}_{2}$ (b) or $\mathbf{1}$ with $\mathbf{2 d}$ in [BMIm][OTf] (c) and [EMPyr][NTf 2 ] (d) under optimized reaction ([Ru-H]:1:2a or $2 \mathrm{~d}=0.01: 1: 1.5,110^{\circ} \mathrm{C}, 6 \mathrm{~h}, 1 \mathrm{~g}$ of IL, inert atmosphere conditions) and extraction $(3 \times 5 \mathrm{~mL}$ of $n$-heptane at $60{ }^{\circ} \mathrm{C}$ or $160-180$ bar of $\mathrm{CO}_{2}$ at $40{ }^{\circ} \mathrm{C}, 8 \mathrm{~mL} / \mathrm{min}, 45 \mathrm{~min}$ ) conditions. The product yields were determined by GC-MS. The extraction yields refer to the mass of products and reactants.

Repetitive batch borylative coupling of $\mathbf{1}$ with $\mathbf{2} \mathbf{d}$ containing a $\mathrm{CO}_{2}$-phlilic trifluoromethyl group gave a very high product yield (over $90 \%$ ) up to the seventh cycle for [BMIm][OTf] and [EMPyr][NTf ${ }_{2}$ ] (Figure 2c,d), respectively). The last three cycles resulted in a slight decrease in the reaction efficiency, 
but it was still at an acceptable level. Nevertheless, high values of cTON were obtained (941-956), showing good system activity.

To investigate the possible cause of the gradual decrease in catalyst activity during the subsequent runs, extracts after the first, second, fifth and eighth runs were analyzed by inductively coupled plasma-mass spectrometry (ICP-MS). The highest ruthenium content was observed for extracts after the first and second runs (7.1-6.6 ppm) if $n$-heptane was applied regardless of the IL used. A pale yellow color was visible in both extracts. Although extracts analyzed after the fifth and eighth cycles were colorless, the ruthenium content was only a bit lower (6.4-4.8 ppm). Clearly better results were observed when $\mathrm{scCO}_{2}$ was used as an extractant. For all ILs, ruthenium content in the analyzed extracts was comparable and lower than $<1 \mathrm{ppm}$. It should be pointed out that, despite significantly lower catalyst leaching in $\mathrm{scCO}_{2}$, the activity of catalytic systems was the same as for processes that used $n$-heptane for extraction. Thus, a gradual decrease in catalyst activity is rather caused by the formation of inactive catalyst species or non-coordinative cyclohexylphosphine oxide than catalyst leaching. Similar observations were made by us during recyclable hydroboration of alkynes in $\left[\mathrm{Ru}(\mathrm{CO}) \mathrm{Cl}(\mathrm{H})\left(\mathrm{PPh}_{3}\right)_{3}\right] @[\mathrm{EMPyr}]\left[\mathrm{NTf}_{2}\right]$ or $\left[\mathrm{Ru}(\mathrm{CO}) \mathrm{Cl}(\mathrm{H})\left(\mathrm{PPh}_{3}\right)_{3}\right] @[\mathrm{EMPyr}][\mathrm{OTf}] / \mathrm{scCO}_{2}$ systems [30].

\subsection{Repetitive Batch Borylative Coupling in the Biphasic Solvent System- $\left[\mathrm{Ru}(\mathrm{CO}) \mathrm{Cl}(\mathrm{H})\left(\mathrm{PC} y_{3}\right)_{2}\right] @ I L s / s c C \mathrm{~S}_{2}$}

In the final stage of our study we performed a repetitive borylative coupling of $\mathbf{1}$ with $\mathbf{2 a}, \mathbf{2 d}$ and $\mathbf{2} \mathbf{j}$ in the biphasic catalytic system $\left[\mathrm{Ru}(\mathrm{CO}) \mathrm{Cl}(\mathrm{H})\left(\mathrm{PCy}_{3}\right)_{2}\right] @[\mathrm{BMIm}][\mathrm{OTf}] / \mathrm{scCO}_{2}$ (Figure $3 \mathrm{a}-\mathrm{c}$ ), respectively). The reactions were performed in 10-mL autoclaves equipped with sapphire windows under optimized reaction and extraction conditions at $180-190$ bar of $\mathrm{scCO}_{2}$ (Figure 3d). Similar to the repetitive trans-borylation of $\mathbf{1}$ with $\mathbf{2 a}$ in $\left[\mathrm{Ru}(\mathrm{CO}) \mathrm{Cl}(\mathrm{H})\left(\mathrm{PCy}_{3}\right)_{2}\right] @[\mathrm{BMIm}][\mathrm{OTf}]$, very high reaction and extraction yields of $\mathbf{3 a}$ in the biphasic solvent system, were observed. Cumulative TON values were comparable to those obtained for the monophasic system (930 vs. 924).

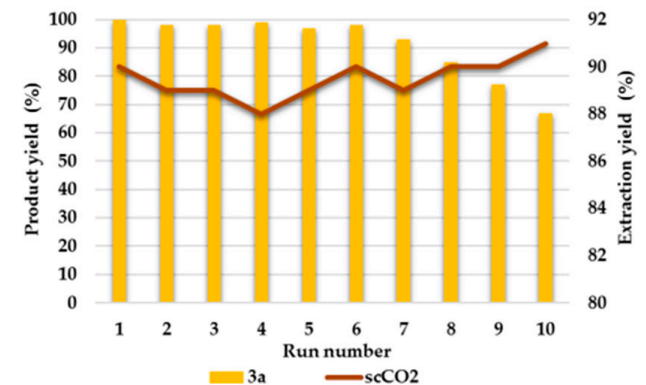

(a)

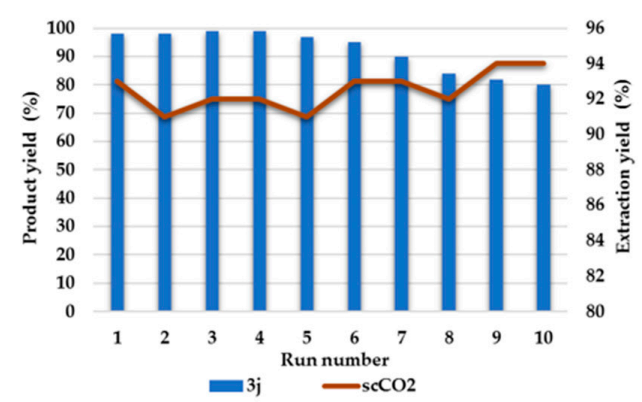

(c)

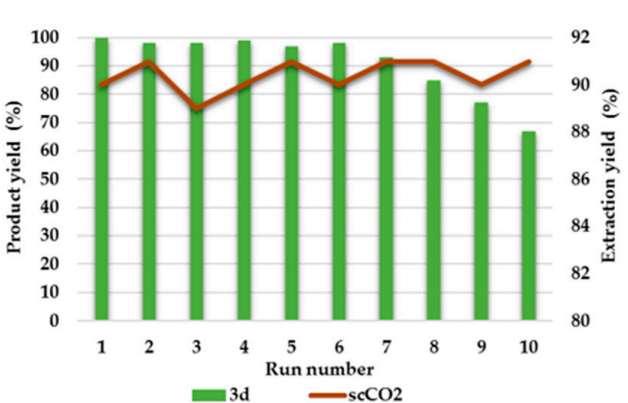

(b)

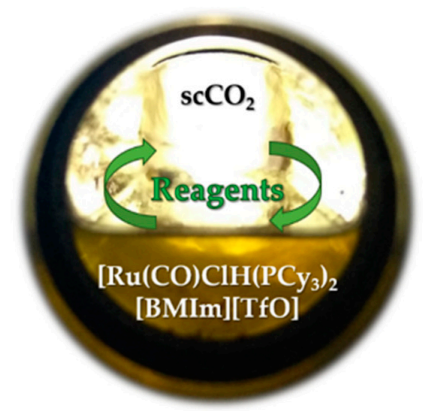

(d)

Figure 3. Repetitive batch borylative coupling of $\mathbf{1}$ with $\mathbf{2 a}(\mathbf{a}), \mathbf{2 d}(\mathbf{b})$ and $\mathbf{2 j}$ (c) in $\left[\mathrm{Ru}(\mathrm{CO}) \mathrm{Cl}(\mathrm{H})\left(\mathrm{PCy}_{3}\right)_{2}\right] @[\mathrm{BMIm}][\mathrm{OTf}] / \mathrm{scCO}_{2}$ biphasic solvent systems under optimized reaction ([Ru-H]:1:2a, $\mathbf{2 d}$ or $\mathbf{2} \mathbf{j}=0.01: 1: 1.5,110{ }^{\circ} \mathrm{C}, 6 \mathrm{~h}, 1 \mathrm{~g}$ of [BMIm][OTf], inert atmosphere conditions) and extraction (160-180 bar of $\mathrm{CO}_{2}$ at $40{ }^{\circ} \mathrm{C}, 8 \mathrm{~mL} / \mathrm{min}, 45 \mathrm{~min}$ ) conditions. Visualization of the reaction mixture through the sapphire window of high-pressure autoclave's $(\mathbf{d})$. The product yields were determined by GC-MS. The extraction yields refer to the mass of products and reactants. 
For 4-(trifluoromethyl)styrene (2d) and vinylcyclohexane (2j), very high reaction and extraction yields of products were observed up to the sixth run, whereupon a gradual decrease in reaction yields was noticed. Extraction yields remained at a very high level regardless of the run. Additionally, the negligible amount of metal in all analyzed extracts $(0.88-0.54 \mathrm{ppm})$ clearly suggested that $\left[\mathrm{Ru}(\mathrm{CO}) \mathrm{Cl}(\mathrm{H})\left(\mathrm{PCy}_{3}\right)_{2}\right]$ was strongly immobilized in [BMIm] [OTf] under applied reaction conditions. The satisfactory stability and activity of the $\left[\mathrm{Ru}(\mathrm{CO}) \mathrm{Cl}(\mathrm{H})\left(\mathrm{PCy}_{3}\right)_{2}\right] @[\mathrm{BMIm}][\mathrm{OTf}] / \mathrm{scCO}_{2}$ system creates an opportunity for its application in continuous-flow borylative coupling reactions in the future.

At the end of our investigation on repetitive batch borylative coupling in the biphasic system, we verified the possibility of direct use of extracts in deborylation protocols, i.e., Suzuki coupling and iododeborylation (Scheme 2).

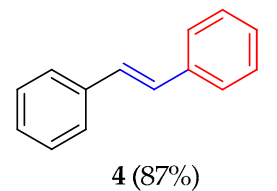

$4(87 \%)$

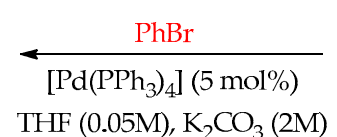

$24 \mathrm{~h}, 60^{\circ} \mathrm{C}$

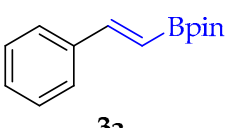

$3 \mathbf{a}$

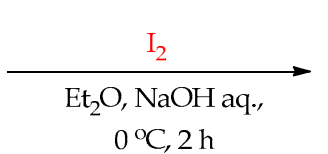

$0^{\circ} \mathrm{C}, 2 \mathrm{~h}$

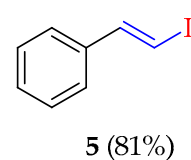

$5(81 \%)$

Scheme 2. Transformations of 3a via Suzuki coupling and iododeborylation reactions.

Suzuki coupling of $3 \mathbf{a}$ with bromobenzene in the presence of $\left[\mathrm{Pd}\left(\mathrm{PPh}_{3}\right)_{4}\right]$ occurred with a complete conversion of 3a and with a very high isolation yield of (E)-1,2-diphenylethene (4) (87\%). Similarly, iododeborylation of 3a with molecular iodine in the presence of sodium hydroxide resulted in a high isolation yield of (E)-(2-iodovinyl)benzene (5) (81\%). The possibility of applying deborylation protocols with the use of crude extract is an attractive approach from the synthetical point of view because of the lack of necessity of carrying out time- and cost-consuming purification steps, for example, column chromatography or distillation.

\section{Materials and Methods}

\subsection{Materials}

Vinylboronic acid pinacol ester (95\%, Sigma-Aldrich), styrene (97\%, Sigma-Aldrich, Poznań, Poland), 4-bromostyrene (97\%, Sigma-Aldrich), 4-fluorostyrene (99\%, Sigma-Aldrich), 4-(trifluoromethyl)styrene (98\%, Sigma-Aldrich), 3,5-bis(trifluoromethyl)styrene (98\%, Alfa Aesar, Kandel, Germany), 4-methylstyrene (96\%, Sigma-Aldrich), 2-methylstyrene (95\%, Sigma-Aldrich), 4-t-butylstyrene (93\%, Sigma-Aldrich), 4-methoxystyrene (97\%, Sigma-Aldrich), vinylcyclohexane (99\%, Sigma-Aldrich) were applied as reagents in borylative coupling reactions. Sodium hydroxide $(99 \%$, POCH Basic, Gliwice, Poland), iodine (99.8\%, Sigma-Aldrich), diethyl ether (99\%, POCH Basic), potassium carbonate (99\%, Sigma-Aldrich), bromobenzene (99\%, Sigma-Aldrich), tetrakis (triphenylphosphine)palladium (0) (99\%, Sigma-Aldrich) were applied as received. 1-Ethyl-1-methylpyrrolidinium trifluoromethanesulfonate (99\%, IoLiTec, Heilbronn, Germany), 1-ethyl-1-methylpyrrolidinium bis(trifluoromethylsulfonyl)imide (98\%, Sigma-Aldrich), 1-butyl-1-methylpyrrolidinium trifluoromethanesulfonate (95\%, Sigma-Aldrich), 1-butyl-1-methylpyrrolidinium bis(trifluoromethylsulfonyl)imide (98\%, Sigma-Aldrich), 1-butyl-3methylimidazolium bis(trifluoromethylsulfonyl)imide (98\%, Sigma-Aldrich), 1-butyl-3methylimidazolium trifluoromethanesulfonate (97\%, Sigma-Aldrich), 1-butyl-3-methylimidazolium hexafluorophosphate (97\%, Sigma-Aldrich), 1-butyl-3-methylimidazolium tetrafluoroborate (98\%, Sigma-Aldrich), 1-butyl-3-methylimidazolium chloride (99\%, Sigma-Aldrich) were dried in a vacuum before use $\left(70{ }^{\circ} \mathrm{C}, 18 \mathrm{~h}\right)$. Styrene, 4-methoxystyrene, and 4-tert-butylstyrene were purified by the bulb to bulb distillation before use. The carbon dioxide (99.995\%, Messer Polska, Chorzów, Poland) was used as a solvent and extractant in the reactions carried out in $\mathrm{scCO}_{2}$. The ruthenium catalysts $\left[\mathrm{Ru}(\mathrm{CO}) \mathrm{Cl}(\mathrm{H})\left(\mathrm{PCy}_{3}\right)_{2}\right][45]$ and $\left[\mathrm{Ru}(\mathrm{CO}) \mathrm{Cl}(\mathrm{H})\left(\mathrm{PPh}_{3}\right)_{3}\right]$ [46] were prepared according to literature procedures. Deuterium solvents were obtained from Dr. Glaser AG Basel. The $n$-hexane $(99 \%$, POCH 
Basic), $n$-heptane (99\%, Sigma-Aldrich), toluene (99\%, POCH Basic), dichloromethane (99\%, POCH Basic), tetrahydrofurane (99\%, POCH Basic) used in the extractions were distilled and dried prior use.

\subsection{General Procedures}

All manipulations were performed under an argon atmosphere using standard Schlenk's techniques or in high-pressure autoclaves equipped with sapphire windows for the solubility tests of reagents and catalyst, when $\mathrm{scCO}_{2}$ was used (For detailed analysis descriptions and NMR spectra of obtained products please see the Supplementary Materials).

\subsubsection{Borylative Coupling in the $\left[\mathrm{Ru}(\mathrm{CO}) \mathrm{Cl}(\mathrm{H})\left(\mathrm{PCy}_{3}\right)_{2}\right] @ I L s$ System under Optimized} Reaction/Extraction Conditions with Subsequent n-Heptane Extraction

A $50 \mathrm{~mL}$ Schlenk's vessel was charged with dried IL $(1 \mathrm{~g})$ and $\left[\mathrm{Ru}(\mathrm{CO}) \mathrm{Cl}(\mathrm{H})\left(\mathrm{PCy}_{3}\right)_{2}\right](0.01 \mathrm{mmol})$ in an argon atmosphere. Subsequently, vinylboronic acid pinacol ester $(0.5 \mathrm{mmol})$ and olefin $(0.75 \mathrm{mmol})$ were added. The reaction was carried out for $6 \mathrm{~h}$ at $110^{\circ} \mathrm{C}$. The reaction mixture was cooled down and the extractant soluble components were extracted at $60^{\circ} \mathrm{C}$ with $n$-heptane $(3 \times 5 \mathrm{~mL})$. After evaporation, the extracts were weighed and characterized by GC-MS and ${ }^{1} \mathrm{H}$ NMR analyses. The products (3a-i) were purified on silica by flash chromatography (Biotage IsoleraOne chromatograph) with a UV detector $\left(\lambda_{1}=255 \mathrm{~nm}, \lambda_{2}=280 \mathrm{~nm}\right)$. Purification details: cartridge $10 \mathrm{~g}$, flow rate: $12 \mathrm{~mL} / \mathrm{min}$, length: $12 \mathrm{CV}(\mathrm{CV}=$ column volume), phase: hexane/ethyl acetate (step 1: hexane $100 \%$ by $5 \mathrm{CV}$, step 2: gradient $10 \% / \mathrm{CV}$ by $5 \mathrm{CV}$, step 3 : hexane $50 \%$ by $2 \mathrm{CV}$ ). The non-aromatic $3 \mathbf{j}$ was purified on silica using standard column chromatography using $n$-hexane/ethyl acetate (95/5-7/3) as eluents. The products were characterized by GC-MS, ${ }^{1} \mathrm{H}$ and ${ }^{13} \mathrm{C}$ NMR analyses.

\subsubsection{Borylative Coupling in the $\left[\mathrm{Ru}(\mathrm{CO}) \mathrm{Cl}(\mathrm{H})\left(\mathrm{PCy}_{3}\right)_{2}\right] @ \mathrm{ILs} / \mathrm{scCO}_{2}$ System with Subsequent} $\mathrm{scCO}_{2}$ Extraction

A high-pressure stainless steel autoclave reactor $(10 \mathrm{~mL})$ equipped with sapphire windows and connected to a Schlenk line, was charged with dried IL $(1 \mathrm{~g})$ and $[\mathrm{Ru}(\mathrm{CO}) \mathrm{Cl}(\mathrm{H})(\mathrm{PCy} 3) 2](0.01 \mathrm{mmol})$ in an argon atmosphere. Subsequently, vinylboronic acid pinacol ester $(0.5 \mathrm{mmol})$ and olefin $(0.75 \mathrm{mmol})$ were added and the reactor was pressurized with $\mathrm{CO}_{2}$ to $55 \mathrm{bar}$, heated up to $110^{\circ} \mathrm{C}$ and pressurized to the required pressure (approx. 170-190 bar). After $6 \mathrm{~h}$, the reactor was cooled to $40{ }^{\circ} \mathrm{C}$ and the products were extracted in a $\mathrm{CO}_{2}$ stream $\left(160-180\right.$ bar of $\left.\mathrm{CO}_{2}, 8 \mathrm{~mL} / \mathrm{min}, 45 \mathrm{~min}\right)$ into a small amount (10-15 mL) of $n$-heptane (previously cooled down in dry ice/i-propanol bath) to avoid product loss during extraction. Then the extracts were evaporated, weighed and characterized by GC-MS and ${ }^{1} \mathrm{H}$ NMR analyses.

\subsubsection{Repetitive Batch Borylative Coupling in $\left[\mathrm{Ru}(\mathrm{CO}) \mathrm{Cl}(\mathrm{H})\left(\mathrm{PCy}_{3}\right)_{2}\right] @ I L s$ with Subsequent Organic} Solvent Extraction

After the extraction process, the Schlenk's vessel was dried under vacuum for $20 \mathrm{~min}$ at $60^{\circ} \mathrm{C}$. Then a new portion of substrates was added in an argon atmosphere and subsequent batches, and extractions were carried out according to the procedure described in Section 3.2.1 without the isolation step.

3.2.4. Repetitive Batch Borylative Coupling in $\left[\mathrm{Ru}(\mathrm{CO}) \mathrm{Cl}(\mathrm{H})(\mathrm{PCy})_{2}\right] @ \mathrm{ILs} / \mathrm{scCO}_{2}$ with Subsequent $\mathrm{scCO}_{2}$ Extraction

After the extraction process, the autoclave was dried in a vacuum for $20 \mathrm{~min}$ at $60{ }^{\circ} \mathrm{C}$. Then a new portion of substrates was added in an argon atmosphere and subsequent batches, and extractions were carried out according to the procedure described in Section 3.2.2. 


\subsubsection{Suzuki Coupling of 3a with Bromobenzene}

A $100 \mathrm{~mL}$ Schlenk vessel equipped with a stirring bar was charged with $\left[\mathrm{Pd}\left(\mathrm{PPh}_{3}\right)_{4}\right](5 \mathrm{~mol} \%)$. Subsequently, THF $(10 \mathrm{~mL}), 3$ a after $\mathrm{scCO}_{2}$ extraction ( $0.5 \mathrm{mmol}$ in $10 \mathrm{~mL}$ of $n$-heptane), bromobenzene $(0.5 \mathrm{mmol})$ and $2 \mathrm{M}$ aqueous solution of $\mathrm{K}_{2} \mathrm{CO}_{3}(20 \mathrm{~mL})$ were added. The reaction was carried out for $24 \mathrm{~h}$ at $50{ }^{\circ} \mathrm{C}$. Then, the organic phase was separated, and the product was purified on silica by flash chromatography with a UV detector $\left(\lambda_{1}=255 \mathrm{~nm}, \lambda_{2}=280 \mathrm{~nm}\right)$ using the purification conditions described in Section 3.2.1 in $87 \%$ yield. The product was characterized by GC-MS, ${ }^{1} \mathrm{H}$ and ${ }^{13} \mathrm{C}$ NMR analyses.

\subsubsection{Iododeborylation of 3a with Molecular Iodine}

To a $100 \mathrm{~mL}$, round-bottom flask equipped with a stirring bar 3a after $\mathrm{scCO}_{2}$ extraction, $10 \mathrm{~mL}$ of $n$-heptane and $5 \mathrm{~mL}$ of diethyl ether were added. Then $2 \mathrm{~mL}$ of the aqueous solution of $\mathrm{NaOH}$ $(3 \mathrm{M})$ was dosed dropwise at $0{ }^{\circ} \mathrm{C}$. Afterward, $\mathrm{I}_{2}(0.85 \mathrm{mmol})$ in diethyl ether $(5 \mathrm{~mL})$ was slowly added. The reaction mixture was stirred for $2 \mathrm{~h}$ and then the excess of iodine was quenched with a saturated solution of sodium thiosulfate. The organic solution was separated, and the aqueous solution was washed with diethyl ether. The volatile organic fractions were evaporated, and the crude product was purified on silica by flash chromatography with a UV detector $\left(\lambda_{1}=255 \mathrm{~nm}, \lambda_{2}=280 \mathrm{~nm}\right)$ using the purification conditions described in Section 3.2.1 in $81 \%$ yield. The product was characterized by GC-MS, ${ }^{1} \mathrm{H}$ and ${ }^{13} \mathrm{C}$ NMR analyses.

\subsection{Product Characterization}

(E)-4,4,5,5-Tetramethyl-2-styryl-1,3,2-dioxaborolane (3a), ${ }^{1} \mathrm{H}$ NMR (300 $\mathrm{MHz}, \mathrm{CDCl}_{3}, 25{ }^{\circ} \mathrm{C}$ ): $\delta=7.49-7.10(\mathrm{~m}, 6 \mathrm{H}, \mathrm{Ph},=\mathrm{C} \underline{\mathrm{H}}(\mathrm{Ph})), 6.09\left(\mathrm{~d}, J_{\mathrm{H}-\mathrm{H}}=18.4 \mathrm{~Hz}, 1 \mathrm{H},=\mathrm{C} \underline{\mathrm{H}}(\mathrm{Bpin})\right), 1.22\left(\mathrm{~s}, 12 \mathrm{H}, \mathrm{CC}_{3}\right) \mathrm{ppm}$. ${ }^{13} \mathrm{C} \mathrm{NMR}\left(75 \mathrm{MHz}, \mathrm{CDCl}_{3}, 25{ }^{\circ} \mathrm{C}\right): \delta=149.6,137.5,129.0,128.6,127.1,83.4\left(\mathrm{CCH}_{3}\right), 24.9\left(\mathrm{CC}_{3}\right) \mathrm{ppm}$. $\mathrm{C}_{\alpha}$ to boron atom was not observed. MS (EI) [m/z (\%)]: 230(M+1 29), 215(21), 187(11), 173(8), 157(14), 144(83), 129(100), 118(14), 105(33), 77(19). Isolated yield: 81\%. NMR and GC-MS data are in agreement with the literature [29].

(E)-2-(4'-Bromostyryl)-4,4,5,5-tetramethyl-1,3,2-dioxaborolane (3b), ${ }^{1} \mathrm{H}$ NMR (300 MHz, acetone- $d_{6}$, $\left.25^{\circ} \mathrm{C}\right): \delta=7.66-7.45(\mathrm{~m}, 4 \mathrm{H}, \mathrm{Ph}), 7.31\left(\mathrm{~d}, J_{\mathrm{H}-\mathrm{H}}=18.4 \mathrm{~Hz}, 1 \mathrm{H},=\mathrm{C} \underline{\mathrm{H}}(\mathrm{Ph})\right), 6.19\left(\mathrm{~d}, J_{\mathrm{H}-\mathrm{H}}=18.4 \mathrm{~Hz}, 1 \mathrm{H}\right.$, $=\mathrm{C} \underline{\mathrm{H}}(\mathrm{Bpin})), 1.28\left(\mathrm{~s}, 12 \mathrm{H}, \mathrm{CC}_{3}\right) \mathrm{ppm} .{ }^{13} \mathrm{C}$ NMR $\left(75 \mathrm{MHz}\right.$, acetone- $\left.d_{6}, 25^{\circ} \mathrm{C}\right): \delta=148.8,137.7,132.8$, $129.9,123.5,84.2\left(\mathrm{CCH}_{3}\right), 25.3\left(\mathrm{CCH}_{3}\right) \mathrm{ppm} . \mathrm{C}_{\alpha}$ to boron atom was not observed. MS (EI) $[\mathrm{m} / z(\%)]$ : 310((M + 2) $\left.{ }^{+}, 21\right), 308\left(\mathrm{M}^{+}, 19\right), 293(17), 222(6), 209(44), 208(41), 143(100), 129(81), 77(59)$. Isolated yield: $77 \%$. NMR and GC-MS data are in agreement with the literature [29].

(E)-2-(4'-Fluorostyryl)-4,4,5,5-tetramethyl-1,3,2-dioxaborolane (3c), ${ }^{1} \mathrm{H}$ NMR (300 MHz, acetone- $d_{6}$, $\left.25^{\circ} \mathrm{C}\right): \delta=7.71-7.55(\mathrm{~m}, 2 \mathrm{H}, \mathrm{Ph}), 7.33\left(\mathrm{~d}, J_{\mathrm{H}-\mathrm{H}}=18.4 \mathrm{~Hz}, 1 \mathrm{H},=\mathrm{C} \underline{\mathrm{H}}(\mathrm{Ph})\right), 7.213-7.09(\mathrm{~m}, 2 \mathrm{H}, \mathrm{Ph}), 6.10$ $\left(\mathrm{d}, J_{\mathrm{H}-\mathrm{H}}=18.4 \mathrm{~Hz}, 1 \mathrm{H},=\mathrm{C} \underline{\mathrm{H}}(\mathrm{Bpin})\right), 1.27\left(\mathrm{~s}, 12 \mathrm{H}, \mathrm{CC}_{3}\right) \mathrm{ppm} .{ }^{13} \mathrm{C} \mathrm{NMR}\left(75 \mathrm{MHz}\right.$, acetone- $\left.d_{6}, 25^{\circ} \mathrm{C}\right):$ $\delta=165.7,162.5,148.8,135.0,130.0,129.9,116.5,116.3,84.0\left(\mathrm{CCH}_{3}\right), 25.2\left(\mathrm{CCH}_{3}\right) \mathrm{ppm} . \mathrm{C}_{\alpha}$ to boron

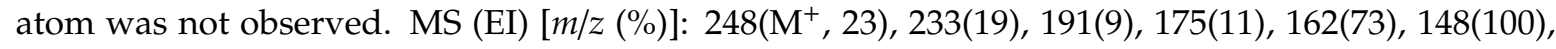
136(21), 123(23), 102(13), 85(19), 57(14). Isolated yield: 78\%. NMR and GC-MS data are in agreement with the literature [29].

(E)-2-(4'-(Trifluoromethyl)styryl)-4,4,5,5-tetramethyl-1,3,2-dioxaborolane (3d), ${ }^{1} \mathrm{H}$ NMR (300 MHz, $\left.\mathrm{CDCl}_{3}, 25^{\circ} \mathrm{C}\right): \delta=7.67-7.49(\mathrm{~m}, 4 \mathrm{H}, \mathrm{Ph}), 7.41\left(\mathrm{~d}, J_{\mathrm{H}-\mathrm{H}}=18.4 \mathrm{~Hz}, 1 \mathrm{H},=\mathrm{C} \underline{\mathrm{H}}(\mathrm{Ph})\right), 6.26\left(\mathrm{~d}, J_{\mathrm{H}-\mathrm{H}}=18.4 \mathrm{~Hz}\right.$, $1 \mathrm{H},=\mathrm{C} \underline{\mathrm{H}}(\mathrm{Bpin})), 1.32\left(\mathrm{~s}, 12 \mathrm{H}, \mathrm{CCH}_{3}\right) \mathrm{ppm} .{ }^{13} \mathrm{C} \mathrm{NMR}\left(75 \mathrm{MHz}, \mathrm{CDCl}_{3}, 25^{\circ} \mathrm{C}\right): \delta=147.8,140.9,130.8$, 130.4, 127.3, 125.8, 125.7, $83.7\left(\mathrm{CCH}_{3}\right), 25.0\left(\mathrm{CCH}_{3}\right)$ ppm. $\mathrm{C}_{\alpha}$ to boron atom was not observed. MS (EI)

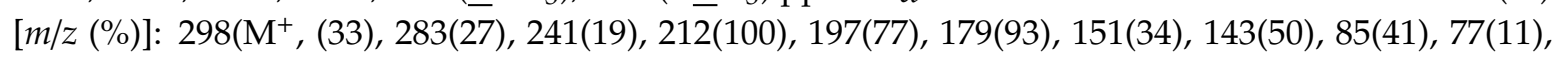
57(30). Isolated yield: $83 \%$. NMR and GC-MS data are in agreement with the literature [29]. 
(E)-2-(3',5'-Bis(trifluoromethyl)styryl)-4,4,5,5-tetramethyl-1,3,2-dioxaborolane (3e), ${ }^{1} \mathrm{H}$ NMR (300 MHz, $\left.\mathrm{CDCl}_{3}, 25^{\circ} \mathrm{C}\right): \delta=7.88(\mathrm{~s}, 2 \mathrm{H}, \mathrm{Ph}), 7.78(\mathrm{~s}, 1 \mathrm{H}, \mathrm{Ph}), 7.41\left(\mathrm{~d}, J_{\mathrm{H}-\mathrm{H}}=18.4 \mathrm{~Hz}, 1 \mathrm{H},=\mathrm{CH}(\mathrm{Ph})\right), 6.31$ $\left(\mathrm{d}, J_{\mathrm{H}-\mathrm{H}}=18.4 \mathrm{~Hz}, 1 \mathrm{H},=\mathrm{C} \underline{\mathrm{H}}(\mathrm{Bpin})\right), 1.32\left(\mathrm{~s}, 12 \mathrm{H}, \mathrm{CC}_{3}\right) \mathrm{ppm} .{ }^{13} \mathrm{C} \mathrm{NMR}\left(75 \mathrm{MHz}, \mathrm{CDCl}_{3}, 25^{\circ} \mathrm{C}\right)$ : $\delta=146.0,139.6,132.2\left(\mathrm{q}, J_{\mathrm{C}-\mathrm{F}}=22.3 \mathrm{~Hz},-\underline{\mathrm{CF}}_{3}\right), 126.9,124.8,122.2,122.0,83.9\left(\underline{\mathrm{CCH}}_{3}\right), 25.0\left(\mathrm{C}_{\mathrm{CH}}\right) \mathrm{ppm}$. $\mathrm{C}_{\alpha}$ to boron atom was not observed. MS (EI) [m/z (\%)]: 366( $\left.\mathrm{M}^{+}, 44\right), 351(39), 347(22), 309(27), 280(100)$, 267(31), 247(77), 211(51), 169(19), 151(25), 97(24), 85(70), 59(77). Isolated yield: 81\%.NMR and GC-MS data are in agreement with the literature [29].

(E)-4,4,5,5-Tetramethyl-2-(4'-methylstyryl)-1,3,2-dioxaborolane (3f), ${ }^{1} \mathrm{H}$ NMR (300 MHz, acetone- $d_{6}$, $\left.25^{\circ} \mathrm{C}\right): \delta=7.46\left(\mathrm{~d}, J_{\mathrm{H}-\mathrm{H}}=8.1 \mathrm{~Hz}, 2 \mathrm{H}, \mathrm{Ph}\right), 7.33\left(\mathrm{~d}, J_{\mathrm{H}-\mathrm{H}}=18.4 \mathrm{~Hz}, 1 \mathrm{H},=\mathrm{C} \underline{\mathrm{H}}(\mathrm{Ph})\right), 7.18\left(\mathrm{~d}, J_{\mathrm{H}-\mathrm{H}}=8.0 \mathrm{~Hz}\right.$, $2 \mathrm{H}, \mathrm{Ph}), 6.09\left(\mathrm{~d}, J_{\mathrm{H}-\mathrm{H}}=18.4 \mathrm{~Hz}, 1 \mathrm{H},=\mathrm{C} \underline{\mathrm{H}}(\mathrm{Bpin})\right), 2.32\left(\mathrm{~s}, 3 \mathrm{H}, 4-\underline{\mathrm{C}}_{3} \mathrm{Ph}\right), 1.27\left(\mathrm{~s}, 12 \mathrm{H}, \mathrm{CC}_{3}\right) \mathrm{ppm}$. ${ }^{13} \mathrm{C} \mathrm{NMR}\left(75 \mathrm{MHz}, \mathrm{CDCl}_{3}, 25{ }^{\circ} \mathrm{C}\right): \delta=149.6,139.0,134.8,129.4,127.1,83.3\left(\mathrm{CCH}_{3}\right), 24.9\left(\mathrm{CCH}_{3}\right), 21.5$ $\left(\mathrm{PhCH}_{3}\right)$ ppm. $\mathrm{C}_{\alpha}$ to boron atom was not observed. MS (EI) [m/z (\%)]: 244( $\left.\mathrm{M}^{+}, 27\right), 229(9), 171(7)$, 158(51), 143(100), 128(41), 117(51), 105(12), 91(19), 77(8), 57(7). Isolated yield: 79\%. NMR and GC-MS data are in agreement with the literature [29].

(E)-4,4,5,5-Tetramethyl-2-(2'-methylstyryl)-1,3,2-dioxaborolane (3g), ${ }^{1} \mathrm{H}$ NMR (300 MHz, acetone- $d_{6}$, $\left.25^{\circ} \mathrm{C}\right): \delta=7.44-7.09(\mathrm{~m}, 5 \mathrm{H}, \mathrm{Ph},=\mathrm{CH}(\mathrm{Ph})), 6.14\left(\mathrm{~d}, J_{\mathrm{H}-\mathrm{H}}=18.4 \mathrm{~Hz}, 1 \mathrm{H},=\mathrm{CH}(\mathrm{Bpin})\right), 2.34(\mathrm{~s}, 3 \mathrm{H}$, 2- $\left.\underline{\mathrm{H}}_{3} \mathrm{Ph}\right), 1.28\left(\mathrm{~s}, 12 \mathrm{H}, \mathrm{CC}_{3}\right) \mathrm{ppm} .{ }^{13} \mathrm{C} \mathrm{NMR}\left(75 \mathrm{MHz}, \mathrm{CDCl}_{3}, 25^{\circ} \mathrm{C}\right): \delta=149.8,138.2,137.5,129.9$, 128.5, 127.9, 124.3, $83.4\left(\underline{\mathrm{CCH}}_{3}\right), 24.9\left(\mathrm{CCH}_{3}\right), 21.5\left(\mathrm{PhCH}_{3}\right) \mathrm{ppm}$. $\mathrm{C}_{\alpha}$ to boron atom was not observed. MS (EI) [m/z (\%)]: 244(M $\left.{ }^{+}, 32\right), 229(12), 171(13), 158(45), 143(100), 128(31), 117(49), 105(11), 91(112)$, 77(8), 57(10). Isolated yield: 69\%. NMR and GC-MS data are in agreement with the literature [29].

(E)-2-(4'-(Tert-butyl)styryl)-4,4,5,5-tetramethyl-1,3,2-dioxaborolane (3h), ${ }^{1} \mathrm{H}$ NMR (300 MHz, acetone $\left.-d_{6}, 25^{\circ} \mathrm{C}\right): \delta=7.49\left(\mathrm{~d}, J_{\mathrm{H}-\mathrm{H}}=8.4 \mathrm{~Hz}, 2 \mathrm{H}, \mathrm{Ph}\right), 7.41\left(\mathrm{~d}, J_{\mathrm{H}-\mathrm{H}}=8.5 \mathrm{~Hz}, 2 \mathrm{H}, \mathrm{Ph}\right), 7.34\left(\mathrm{~d}, J_{\mathrm{H}-\mathrm{H}}=18.4 \mathrm{~Hz}\right.$, $1 \mathrm{H},=\mathrm{C} \underline{\mathrm{H}}(\mathrm{Ph})), 6.11\left(\mathrm{~d}, J_{\mathrm{H}-\mathrm{H}}=18.4 \mathrm{~Hz}, 1 \mathrm{H},=\mathrm{C} \underline{\mathrm{H}}(\mathrm{Bpin})\right), 1.31(\mathrm{~s}, 9 \mathrm{H}, 4-t-\underline{\mathrm{BuPh}}), 1.28\left(\mathrm{~s}, 12 \mathrm{H}, \mathrm{CC}_{3}\right) \mathrm{ppm}$. ${ }^{13} \mathrm{C}$ NMR $\left(75 \mathrm{MHz}\right.$, acetone- $\left.d_{6}, 25^{\circ} \mathrm{C}\right): \delta=153.1,150.2,135.8,127.8,126.5,83.9\left(\mathrm{CCH}_{3}\right), 35.4, \overline{31} .6,25.3$

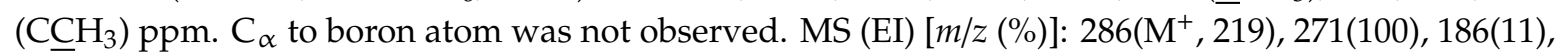
171(19), 155(15), 143(23), 129(9), 83(10), 57(13). Isolated yield: 73\%. NMR and GC-MS data are in agreement with the literature [29].

(E)-2-(4'-Methoxystyryl)-4,4,5,5-tetramethyl-1,3,2-dioxaborolane (3i), ${ }^{1} \mathrm{H}$ NMR $\left(300 \mathrm{MHz}, \mathrm{CDCl}_{3}\right.$, $\left.25^{\circ} \mathrm{C}\right): \delta=7.44\left(\mathrm{~d}, J_{\mathrm{H}-\mathrm{H}}=8.7 \mathrm{~Hz}, 2 \mathrm{H}, \mathrm{Ph}\right), 7.35\left(\mathrm{~d}, J_{\mathrm{H}-\mathrm{H}}=18.4 \mathrm{~Hz}, 1 \mathrm{H},=\mathrm{C} \underline{\mathrm{H}}(\mathrm{Ph})\right), 6.86\left(\mathrm{~d}, J_{\mathrm{H}-\mathrm{H}}=8.7 \mathrm{~Hz}\right.$, $2 \mathrm{H}, \mathrm{Ph}), 6.01\left(\mathrm{~d}, J_{\mathrm{H}-\mathrm{H}}=18.4 \mathrm{~Hz}, 1 \mathrm{H},=\mathrm{C} \underline{\mathrm{H}}(\mathrm{Bpin})\right), 3.81\left(\mathrm{~s}, 3 \mathrm{H}, 4-\mathrm{OC}_{3} \mathrm{Ph}\right), 1.31\left(\mathrm{~s}, 12 \mathrm{H}, \mathrm{CC}_{3}\right) \mathrm{ppm}$. ${ }^{13} \mathrm{C} \mathrm{NMR}\left(75 \mathrm{MHz}, \mathrm{CDCl}_{3}, 25{ }^{\circ} \mathrm{C}\right): \delta=160.4,149.2,130.5,128.6,114.1,83.3\left(\mathrm{CCH}_{3}\right), 55.4,25.0\left(\mathrm{CCH}_{3}\right)$ ppm. $\mathrm{C}_{\alpha}$ to boron atom was not observed. MS (EI) [m/z (\%)]: 260( $\left.\mathrm{M}^{+}, 39\right), 245(10), 187(9), 174(25)$, 160(64), 144(100), 129(17), 117(31), 91(19), 77(31), 57(16). Isolated yield: 71\%.NMR and GC-MS data are in agreement with the literature [29].

(E)-2-(2-Cyclohexylvinyl)-4,4,5,5-tetramethyl-1,3,2-dioxaborolane (3j), ${ }^{1} \mathrm{H} \mathrm{NMR}\left(300 \mathrm{MHz}, \mathrm{CDCl}_{3}\right.$, $\left.25^{\circ} \mathrm{C}\right): \delta=6.57\left(\mathrm{dd}, J_{\mathrm{H}-\mathrm{H}}=18.2,6.2 \mathrm{~Hz}, 1 \mathrm{H},=\mathrm{C} \underline{\mathrm{H}}(\mathrm{c}-\mathrm{hexyl})\right), 5.37\left(\mathrm{~d}, J_{\mathrm{H}-\mathrm{H}}=18.2 \mathrm{~Hz}, 1 \mathrm{H},=\mathrm{C} \underline{\mathrm{H}}(\right.$ Bpin $\left.)\right)$, $1.83-1.55(\mathrm{~m}, 7 \mathrm{H}), 1.26\left(\mathrm{~s}, 12 \mathrm{H}, \mathrm{CC}_{3}\right), 1.22-1.00(\mathrm{~m}, 4 \mathrm{H}) \mathrm{ppm} .{ }^{13} \mathrm{C} \mathrm{NMR}\left(75 \mathrm{MHz}, \mathrm{CDCl}_{3}, 25{ }^{\circ} \mathrm{C}\right)$ : $\delta=160.1,83.1\left(\mathrm{CCH}_{3}\right), 43.4,32.0,26.3,26.1,24.9\left(\mathrm{C}^{-} H_{3}\right)$ ppm. $\mathrm{C}_{\alpha}$ to boron atom was not observed.

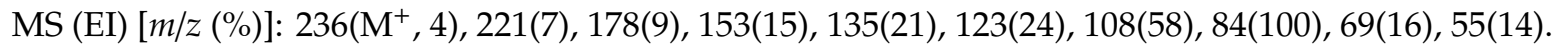
Isolated yield: $87 \%$. NMR and GC-MS data are in agreement with the literature [29].

(E)-1,2-Diphenylethene (4), ${ }^{1} \mathrm{H}$ NMR $\left(300 \mathrm{MHz}, \mathrm{CDCl}_{3}, 25^{\circ} \mathrm{C}\right): \delta=7.57\left(\mathrm{~d}, J_{\mathrm{H}-\mathrm{H}}=8.0 \mathrm{~Hz}, 4 \mathrm{H}\right)$,

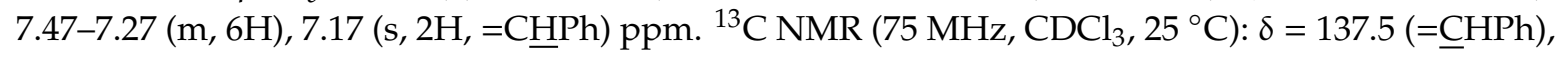
$128.8,127.8,126.6 \mathrm{ppm}$. MS (EI) [ $\mathrm{m} / \mathrm{z}(\%)]: 180\left(\mathrm{M}^{+}, 100\right), 165(22), 152(12), 102(11), 89(15), 77(11)$. Isolated yield: $87 \%$. NMR and GC-MS data are in agreement with the literature [32].

(E)-(2-Iodovinyl)benzene (5), ${ }^{1} \mathrm{H} \mathrm{NMR}\left(300 \mathrm{MHz}, \mathrm{CDCl}_{3}, 25^{\circ} \mathrm{C}\right) \delta=7.42\left(\mathrm{~d}, \mathrm{~J}_{\mathrm{H}-\mathrm{H}}=14.9 \mathrm{~Hz}, 1 \mathrm{H}\right.$, $=\mathrm{C} \underline{\mathrm{H}}), 7.28-7.08(\mathrm{~m}, 5 \mathrm{H}), 6.77\left(\mathrm{~d}, J_{\mathrm{H}-\mathrm{H}}=14.9 \mathrm{~Hz}, 1 \mathrm{H},=\mathrm{CH}\right) .{ }^{13} \mathrm{C} \mathrm{NMR}\left(75 \mathrm{MHz}, \mathrm{CDCl}_{3}, 25{ }^{\circ} \mathrm{C}\right)$ $\delta 144.95,138.48,135.15,129.51,126.02,75.49$. MS (EI) [m/z (\%)]: 230(M+, 100), 127(13), 103(85), 77(53). Isolated yield: $81 \%$. NMR and GC-MS data are in agreement with the literature [34]. 


\section{Conclusions}

The new, effective and highly regio- and stereoselective catalytic systems based on the immobilization of $\left[\mathrm{Ru}(\mathrm{CO}) \mathrm{Cl}(\mathrm{H})\left(\mathrm{PCy}_{3}\right)_{2}\right]$ in ionic liquids for the borylative coupling of vinylboronic pinacol ester with olefins was presented for the first time within these studies. The best results, characterized by excellent product yields, were obtained when [BMIm][OTf] and [EMPyr][NTf $\left.{ }_{2}\right]$ were used as solvents and catalyst immobilization media. The system permitted a transformation of various vinyl-substituted olefins (styrene (2a), functionalized styrenes (2b-i) and vinylcyclohexane (2j)) into useful borylsubstituted unsaturated products, which can be used in deborylation or Suzuki coupling reactions. The application of ILs permitted catalyst reuse and the carrying out of repetitive batch borylative coupling in monophasic $\left[\mathrm{Ru}(\mathrm{CO}) \mathrm{Cl}(\mathrm{H})\left(\mathrm{PCy}_{3}\right)_{2}\right] @ \mathrm{ILs}$ or biphasic $\left[\mathrm{Ru}(\mathrm{CO}) \mathrm{Cl}(\mathrm{H})(\mathrm{PCy})_{2}\right] @[\mathrm{BMIm}][\mathrm{OTf}] / \mathrm{scCO}_{2}$ systems with product extraction with non-polar $n$-heptane or $\mathrm{scCO}_{2}$. These new protocols, under optimized reaction $\left([\mathrm{Ru}-\mathrm{H}]: 1: 2=0.01: 1: 1.5,110{ }^{\circ} \mathrm{C}, 6 \mathrm{~h}, 1 \mathrm{~g} \mathrm{IL}\right.$, inert atmosphere conditions) and extraction $\left(3 \times 5 \mathrm{~mL}\right.$ of the $n$-heptane at $60^{\circ} \mathrm{C}$ or $160-180$ bar of $\mathrm{CO}_{2}$ at $40{ }^{\circ} \mathrm{C}, 8 \mathrm{~mL} / \mathrm{min}, 45 \mathrm{~min}$ ) conditions, allowed of the catalyst to be reused 5-7 times without any significant loss of activity or stability. The application of $\mathrm{scCO}_{2}$ as an extractant in monophasic or biphasic solvent systems significantly reduced catalyst leaching during the separation process $(<1 \mathrm{ppm}$ in each batch), compared to the extraction with $n$-heptane. Moreover, the good solubility of the reagents and products in $\mathrm{scCO}_{2}$ and the high catalyst stability creates future possibilities for carrying out this process under a continuous flow method. In addition, it was found that the application of ILs as reaction media has a positive impact on the reaction rate, shortening the process from $24 \mathrm{~h}$ to $6 \mathrm{~h}$. Such an approach based on multiple catalyst use enabled an intensification of the cumulative TON values (up to 956) in comparison to the single batch ( 50-100), showing the potential of the system reported within this research, which was developed according to the sustainable development rules. The catalyst reuse, simplification of the separation process, increased process productivity and possibilities to carry out the reaction in repetitive batch borylative coupling of olefins are in agreement with green chemistry paradigms.

Supplementary Materials: The following are available online at http://www.mdpi.com/2073-4344/10/7/762/s1, Procedure description of GC-MS, NMR and ICP-MS analyses, NMR spectra for all isolated products $(\mathbf{3} \mathbf{a}-\mathbf{j}, \mathbf{4}, \mathbf{5})$.

Author Contributions: Conceptualization, J.S. and J.W.; methodology, J.S. and J.W.; investigation, J.S. and T.S.; resources, J.S., T.S., A.F. and J.W.; writing-original draft preparation, J.S.; writing-review and editing, J.W., A.F., T.S. and J.S.; supervision, J.W.; funding acquisition, T.S. All authors have read and agreed to the published version of the manuscript.

Funding: The APC was funded by grant No. POWR.03.02.00-00-I026/16 co-financed by the EU through the European Social Fund under the Operational Program Knowledge Education Development.

Acknowledgments: This work was supported by The National Centre for Research and Development in Poland, Lider Programme No. LIDER/26/527/L-5/13/NCBR/2014 and The National Science Centre No. UMO-2019/32/C/ST4/00235 and The National Centre for Research and Development in Poland, Lider Programme No. LIDER/6/0017/L-9/17/NCBR/2018 and grant No. POWR.03.02.00-00-I026/16 co-financed by the EU through the European Social Fund under the Operational Program Knowledge Education Development.

Conflicts of Interest: The authors declare no conflict of interest.

\section{References}

1. Bhaduri, S.; Mukesh, D. Chemical industry and homogeneous catalysis. In Homogeneous Catalysis; Bhaduri, S., Mukesh, D., Eds.; John Wiley \& Sons, Inc.: Hoboken, NJ, USA, 2014; pp. 1-21.

2. Joshi, S.S.; Bhatnagar, A.; Ranade, V.V. Chapter 8-Catalysis for fine and specialty chemicals. In Industrial Catalytic Processes for Fine and Specialty Chemicals; Joshi, S.S., Ranade, V.V., Eds.; Elsevier: Amsterdam, The Netherlands, 2016; pp. 317-392.

3. Cole-Hamilton, D.J.; Tooze, R.P. Catalyst Separation, Recovery and Recycling: Chemistry and Process Design; Springer Science \& Business Media: Berlin/Heidelberg, Germany, 2006; Volume 30, pp. 1-247.

4. Centi, G.; Perathoner, S. Methods and tools of sustainable industrial chemistry: Catalysis. Sustain. Ind. Chem. 2009, 73-198. [CrossRef] 
5. Shende, V.S.; Saptal, V.B.; Bhanage, B.M. Recent advances utilized in the recycling of homogeneous catalysis. Chem. Rec. 2019, 19, 2022-2043. [CrossRef] [PubMed]

6. Cole-Hamilton, D.J. Homogeneous catalysis-New approaches to catalyst separation, recovery, and recycling. Science 2003, 299, 1702-1706. [CrossRef] [PubMed]

7. Clarke, C.J.; Tu, W.-C.; Levers, O.; Bröhl, A.; Hallett, J.P. Green and sustainable solvents in chemical processes. Chem. Rev. 2018, 118, 747-800. [CrossRef] [PubMed]

8. Walkowiak, J.; Franciò, G.; Leitner, W. Supercritical fluids as advanced media for reaction and separation in homogeneous catalysis. In Applied Homogeneous Catalysis with Organometallic Compounds: A Comprehensive Handbook in Four Volumes; Wiley-VCH Verlag GmbH \& Co. KGaA.: Weinheim, Germany, 2018; pp. 1221-1258.

9. Bermúdez, M.-D.; Jiménez, A.-E.; Sanes, J.; Carrión, F.-J. Ionic liquids as advanced lubricant fluids. Molecules 2009, 14, 2888-2908. [CrossRef]

10. Zhou, F.; Liang, Y.; Liu, W. Ionic liquid lubricants: Designed chemistry for engineering applications. Chem. Soc. Rev. 2009, 38, 2590-2599. [CrossRef] [PubMed]

11. Zhao, Y.; Bostrom, T. Application of ionic liquids in solar cells and batteries: A review. Curr. Org. Chem. 2015, 19, 556-566. [CrossRef]

12. MacFarlane, D.R.; Tachikawa, N.; Forsyth, M.; Pringle, J.M.; Howlett, P.C.; Elliott, G.D.; Davis, J.H.; Watanabe, M.; Simon, P.; Angell, C.A. Energy applications of ionic liquids. Energy Environ. Sci. 2014, 7, 232-250. [CrossRef]

13. Tan, S.S.Y.; MacFarlane, D.R. Ionic liquids in biomass processing. In Ionic Liquids; Springer: Berlin/Heidelberg, Germany, 2009; pp. 311-339.

14. Tadesse, H.; Luque, R. Advances on biomass pretreatment using ionic liquids: An overview. Energy Environ. Sci. 2011, 4, 3913-3929. [CrossRef]

15. Vekariya, R.L. A review of ionic liquids: Applications towards catalytic organic transformations. J. Mol. Liq. 2017, 227, 44-60. [CrossRef]

16. Welton, T. Ionic liquids in catalysis. Coord. Chem. Rev. 2004, 248, 2459-2477. [CrossRef]

17. Pârvulescu, V.I.; Hardacre, C. Catalysis in ionic liquids. Chem. Rev. 2007, 107, 2615-2665. [CrossRef]

18. Blanchard, L.A.; Brennecke, J.F. Recovery of organic products from ionic liquids using supercritical carbon dioxide. Ind. Eng. Chem. Res. 2001, 40, 287-292. [CrossRef]

19. Jutz, F.; Andanson, J.-M.; Baiker, A. Ionic liquids and dense carbon dioxide: A beneficial biphasic system for catalysis. Chem. Rev. 2011, 111, 322-353. [CrossRef] [PubMed]

20. Jessop, P.G.; Stanley, R.R.; Brown, R.A.; Eckert, C.A.; Liotta, C.L.; Ngo, T.T.; Pollet, P. Neoteric solvents for asymmetric hydrogenation: Supercritical fluids, ionic liquids, and expanded ionic liquids. Green Chem. 2003, 5, 123-128. [CrossRef]

21. Geier, D.; Schmitz, P.; Walkowiak, J.; Leitner, W.; Franciò, G. Continuous flow asymmetric hydrogenation with supported ionic liquid phase catalysts using modified $\mathrm{CO} 2$ as the mobile phase: From model substrate to an active pharmaceutical ingredient. ACS Catal. 2018, 8, 3297-3303. [CrossRef]

22. Muzart, J. Ionic liquids as solvents for catalyzed oxidations of organic compounds. Adv. Synth. Catal. 2006, 348, 275-295. [CrossRef]

23. Rieger, B.; Plikhta, A.; Castillo-Molina, D.A. Ionic liquids in transition metal-catalyzed hydroformylation reactions. In Ionic Liquids (ILs) in Organometallic Catalysis; Dupont, J., Kollár, L., Eds.; Springer: Berlin/Heidelberg, Germany, 2015; pp. 95-144.

24. Li, J.; Yang, S.; Wu, W.; Jiang, H. Recent advances in Pd-catalyzed cross-coupling reaction in ionic liquids. Eur. J. Org. Chem. 2018, 2018, 1284-1306. [CrossRef]

25. Maciejewski, H.; Szubert, K.; Marciniec, B.; Pernak, J. Hydrosilylation of functionalised olefins catalysed by rhodium siloxide complexes in ionic liquids. Green Chem. 2009, 11, 1045-1051. [CrossRef]

26. Maciejewski, H.; Szubert, K.; Marciniec, B. New approach to synthesis of functionalised silsesquioxanes via hydrosilylation. Catal. Commun. 2012, 24, 1-4. [CrossRef]

27. Maciejewski, H.; Szubert, K.; Fiedorow, R.; Giszter, R.; Niemczak, M.; Pernak, J.; Klimas, W. Diallyldimethylammonium and trimethylvinylammonium ionic liquids-Synthesis and application to catalysis. Appl. Catal. A 2013, 451, 168-175. [CrossRef]

28. Rogalski, S.; Żak, P.; Miętkiewski, M.; Dutkiewicz, M.; Fiedorow, R.; Maciejewski, H.; Pietraszuk, C.; Śmiglak, M.; Schubert, T.J. Efficient synthesis of E-1, 2-bis (silyl) ethenes via ruthenium-catalyzed homocoupling of vinylsilanes carried out in ionic liquids. Appl. Catal. A 2012, 445, 261-268. [CrossRef] 
29. Szyling, J.; Walkowiak, J.; Sokolnicki, T.; Franczyk, A.; Stefanowska, K.; Klarek, M. PEG-mediated recyclable borylative coupling of vinyl boronates with olefins. J. Catal. 2019, 376, 219-227. [CrossRef]

30. Szyling, J.; Franczyk, A.; Stefanowska, K.; Maciejewski, H.; Walkowiak, J.d. Recyclable hydroboration of alkynes using RuH@ IL and RuH@ IL/scCO2 catalytic systems. ACS Sustain. Chem. Eng. 2018, 6, 10980-10988. [CrossRef]

31. Szyling, J.; Franczyk, A.; Stefanowska, K.; Klarek, M.; Maciejewski, H.; Walkowiak, J. An effective catalytic hydroboration of alkynes in supercritical CO2 under repetitive batch mode. ChemCatChem 2018, 10, 531-539. [CrossRef]

32. Szyling, J.; Franczyk, A.; Stefanowska, K.; Walkowiak, J. A recyclable Ru (CO) Cl (H)(PPh3) 3/PEG catalytic system for regio-and stereoselective hydroboration of terminal and internal alkynes. Adv. Synth. Catal. 2018, 360, 2966-2974. [CrossRef]

33. Stefanowska, K.; Franczyk, A.; Szyling, J.; Salamon, K.; Marciniec, B.; Walkowiak, J. An effective hydrosilylation of alkynes in supercritical CO2-A green approach to alkenyl silanes. J. Catal. 2017, 356, 206-213. [CrossRef]

34. Szyling, J.; Franczyk, A.; Pawluć, P.; Marciniec, B.; Walkowiak, J. A stereoselective synthesis of (E)-or (Z)- $\beta$-arylvinyl halides via a borylative coupling/halodeborylation protocol. Org. Biomol. Chem. 2017, 15, 3207-3215. [CrossRef]

35. Szyling, J.; Walkowiak, J. Effective one-pot synthesis of (E)-poly (vinyl arylenes) via trans-borylation/Suzuki coupling protocol. Green Proc. Synth. 2017, 6, 301-310. [CrossRef]

36. Denmark, S.E.; Tymonko, S.A. Sequential cross-coupling of 1, 4-bissilylbutadienes: Synthesis of unsymmetrical 1, 4-disubstituted 1, 3-butadienes. J. Am. Chem. Soc. 2005, 127, 8004-8005. [CrossRef]

37. Carreras, J.; Caballero, A.; Pérez, P.J. Alkenyl boronates: Synthesis and applications. Chem. Asian J. 2019, 14, 329-343. [CrossRef]

38. Pawluć, P.; Franczyk, A.; Walkowiak, J.; Hreczycho, G.; Kubicki, M.; Marciniec, B. (E)-9-(2-Iodovinyl)-9H-carbazole: A new coupling reagent for the synthesis of $\pi$-conjugated carbazoles. Org. Lett. 2011, 13, 1976-1979. [CrossRef]

39. Aubin, S.; Le Floch, F.; Carrié, D.; Guegan, J.P.; Vaultier, M. Transition-metal-catalyzed hydrosilylation and hydroboration of terminal alkynes in ionic liquids. In Ionic Liquids; ACS Symposium Series; American Chemical Society: Washington, DC, USA, 2002; Volume 818, pp. 334-346.

40. Marciniec, B.; Jankowska, M.; Pietraszuk, C. New catalytic route to functionalized vinylboronates. Chem. Commun. 2005, 663-665. [CrossRef] [PubMed]

41. Marciniec, B.; Walkowiak, J. Ruthenium (II) complex catalyzed O-borylation of alcohols with vinylboronates. Synlett 2009, 2009, 2433-2436. [CrossRef]

42. Marciniec, B.; Walkowiak, J. New catalytic route to borasiloxanes. Chem. Commun. 2008, $2695-2697$. [CrossRef] [PubMed]

43. Walkowiak, J.; Marciniec, B. A new catalytic method for the synthesis of boroxanes. Tetrahedron Lett. 2010, 51, 6177-6180. [CrossRef]

44. Blanchard, L.A.; Gu, Z.; Brennecke, J.F. High-pressure phase behavior of ionic liquid/CO2 systems. J. Phys. Chem. B 2001, 105, 2437-2444. [CrossRef]

45. Yi, C.S.; Lee, D.W.; Chen, Y. Hydrovinylation and [2 + 2] cycloaddition reactions of alkynes and alkenes catalyzed by a well-defined cationic ruthenium-Alkylidene complex. Organometallics 1999, 18, 2043-2045. [CrossRef]

46. Ahmad, N.; Levison, J.J.; Robinson, S.; Uttley, M.; Wonchoba, E.; Parshall, G. Complexes of ruthenium, osmium, rhodium, and iridium containing hydride carbonyl, or nitrosyl ligands. Inorg. Synth. 1974, 15, 45-64.

(C) 2020 by the authors. Licensee MDPI, Basel, Switzerland. This article is an open access article distributed under the terms and conditions of the Creative Commons Attribution (CC BY) license (http://creativecommons.org/licenses/by/4.0/). 